\title{
The Exploration of Circumstance: Casuistry and the Emergence of the Novela Bizantina in Alonso Núñez de Reinoso's Historia de los amores de Clareo y Florisea, y de los trabajos de Ysea (1552)
}

\author{
Anita Traninger
}

\begin{abstract}
Despite being variously referred to as a romance of love and adventure, the Golden Age novela bizantina is hardly limited to narrating amorous exploits. Rather, it tends to treat of displacement and destitution, thereby confronting its characters with existential cases of conscience. This article explores how the first Spanish novel of this kind, Alonso Núñez de Reinoso's Los amores de Clareo y Florisea y los trabajos de la sin ventura Isea (1552) engages its readers in moral reflection.
\end{abstract}

\section{Keywords}

Núñez de Reinoso - Greek novel - novela bizantina - Achilles Tatius - casuistry Second Sophistic - Venice - Sephardic jews - diaspora

The so-called novela bizantina, which is the early modern Spanish-language appropriation of the Greek prose novel, has not yet been connected with casuistry or thinking about cases in general. ${ }^{1}$ This may have to do with the genre's reputation as idealizing romance, offering schematic sentimental plot lines that do not betray an interest in human psychology or moral crisis. The stories of virtuous and chaste lovers separated by shipwreck, pirates, abductions and mock executions, eventually reunited unscathed, inspired Mikhail Bakhtin's concept of the chronotope and more specifically that of adventure time. And they were of course relentlessly mocked by Voltaire in his Candide. But they have not been construed as vehicles of moral reflection.

1 I gratefully acknowledge the funding received from the German Research Association (DFG) in support of the research for this chapter in the framework of the research group FOR 2305 "Discursivisations of the New" at Freie Universität Berlin. 
The very first exemplar of the emerging genre set the tone for subsequent texts, despite mixing several generic traditions and being not at all typical of what would become the novela bizantina. It does, however, lead the way in accommodating moral philosophical concerns, both by raising them in the paratexts and by staging them in the narrative. Alonso Núñez de Reinoso, a Portuguese converso in Venetian exile under the protection of the powerful Mendoza/Nasi family, which at the very time sponsored the exodus of thousands of Sephardic Jews to the Ottoman empire, ${ }^{2}$ published the Historia de los amores de Clareo y Florisea, $y$ de los trabajos de Ysea in Venice in 1552. The novel's dedicatee, Juan Micas - who would later, under the name of Joseph Nasi, become the duke of Naxos - was already installed at Constantinople when Reinoso wrote the book. He had closed a deal with the Sultan to let the Portuguese conversos who had reached Venice with the help of his family (and in particular his aunt, Gracia Mendes, also known as Beatriz de Luna), migrate to the Ottoman Empire. In a letter by Felipe II dating from October 1569 he was later declared an enemy of Christendom (Teijeiro Fuentes 1991: 59). Against this backdrop, the predominant reading of Reinoso's novel is that of an ego document, a "fictional journal which is the factual catalogue of his misfortunes" as Constance Hubbard Rose put it (Rose 1983: 102). Isea, the strange third character alongside the conventional virtuous couple, has variously been construed as Reinoso's persona, not only as a narrative device, but as a stand-in for his real-life experience that is allegedly allegorised in the story. ${ }^{3}$ Reinoso's situation as a Portuguese converso in Venetian exile seems to suggest that the text is an echo of a personal experience of displacement and deprivation.

Reinoso's bibliography is short. Apart from Clareo y Florisea, there is only a collection of "obras en verso" which were appended to the novel as the second part of the volume. Hence the full title: Historia de los amores de Clareo $y$ Florisea, $y$ de los trabajos de Ysea: Con otras obras en verso, parte al estilo Español, y parte al Italiano: agora nuevamente sacada a luz. The octavo volume, extending to no more than 200 pages for the novel and 136 for the coplas castellanas y versos al estilo italiano, was printed by Gabriel Giolito de Ferrari and his brothers - once, as there is no evidence of further editions. An apology that follows the Italianate, yet Castilian coplas points to the community of strangers involved in the production of the book, with Venetian typesetters composing a Castilian text: "Y siendo los que componian, estrangeros, y poco platicos en la lengua Castellana, no podra dexar de auer yerros de letras, que faltarean o sobraran, o estaran puestas unas por otras [...]" (Núñez de Reinoso II, 135). The

2 For this context, see Grunebaum-Ballin; Saporta Beja; Rose 1970.

3 For this substitute function see in particular Bataillon. 
diverse group that produced the volume is indicative of the lively and international intellectual milieu in which the traditional love and adventure story became tied to moral philosophical concerns.

\section{A Tale of Love and Loss}

The title page, presenting Clareo and Florisea together with a certain Isea as protagonists, as well as the header for the story, which eventually not only names Reinoso as the author but which also characterises Isea as "sin ventura" (65), appears to point to a love triangle, a story of love and jealousy. And indeed, in chapters one to nineteen, this is exactly what unfolds. Clareo, a native of Constantinople, falls in love with his niece Florisea. They flee towards Alexandria and, despite being madly in love, remain chaste as if they were (close) siblings (this being a motif taken from Heliodorus, see Marguet 14). In Alexandria, Florisea is abducted by a pirate, who appears to decapitate her and throw her lifeless body into the sea. Isea, a nineteen-year-old widow, falls in love with the now single Clareo. Her name is a truncated version of her beheaded predecessor; she is a "de-flowered" Florisea. Clareo, after much wooing by Isea, who has fallen helplessly for him, eventually consents to marriage under the condition that it must not be consummated. They decide to sail to Ephesos, Isea's hometown, where she buys a female slave, not being aware that she is none other than Florisea (who is not dead after all). Also, Tesiandro Isea's husband, whom she had also thought dead - returns and falls in love with Florisea. For some reason Clareo, unaware of these events, confesses that he had murdered Florisea. The Ephesians sentence him to death, but Florisea appears in the nick of time and saves him. Clareo and Florisea get married and return to Byzantium.

This is the end of the 'classical' Greek tale, but it is not the end of the story. While the reunited couple takes off to live happily ever after, it is Isea who is left behind. She decides that it is time for her to leave home, to roam the world and find the place in which death would finally release her from her pain ("e irme por ese mundo hasta ver en qué lugar la muerte querría acabar mi vida, y las duras parcas cortar los hilos de la triste tela, y la dura tierra querría recoger este mi cansado cuerpo," 137).

Thus commences the second part, which sees Isea again heading towards Alexandria, where she encounters a knight errant who inexplicably travels in full armour on a black horse, accompanied by four valets carrying his weapons (144). He is Felesindos de Trapisonda, the nephew of the Emperor of Trebizond and son of the former King of Bohemia. Surpassing Ulysses, as the novel claims, 
he has been on the road for many years in search of the princess Luciandra with whom he is in love and who had disappeared from court without a trace. The following ten chapters detail a sequence of knightly pursuits. While Isea, who is the story's first-person narrator, is present per conventionem, she is a virtually invisible observer in these episodes. After a long series of adventurous (but eventually pointless) pursuits, Felesindos - who by now calls himself "el caballero de Esperas Dudosas" (171) - is invited by servants of Venus and Pallas to a battle of the goddesses in Argos, a battle in which all the great caballeros of the world are supposed to take part (173). The two goddesses give speeches to convince the assembled knights to fight for their respective side. Felesindos is of the smaller group who decides to join Venus' army; they are immediately at a disadvantage, not only because of their numbers, but because the army of lovers "peleaban muy flacamente" (177). In a last-minute relief campaign, more knights, "todos armados al hábito pastoril" (177), are brought in for Venus' side, which eventually wins.

Felesindos and Isea march on towards the "casa de la fama", "la cual está en una región entre el aire y el cielo y el mar” (179), a borrowing from Ovid's Metamorphoses (XII, 39-40), and then to the "casa del gran sabio," "la cual estaba metida entre altas sierras y montes" (183). The wise man leads them to the río del olvido, telling them that if they drink from its waters, all their sorrows will be erased. Both decline. After a detour to the underworld, where Pluto reigns (185) - Isea again not engaging with her company, but rather muttering her observations to herself ("decía conmigo misma", 187 ; "decía yo conmigo", 188) - the wise man sends Felesindos off to the casa del Descanso where he will find Luciandra. After a tearful goodbye, Isea and Felesindos part ways. She sets her mind on becoming a nun and heads towards Europe. After being rejected from a monastery in Spain because of her lack of financial means, she moves on in search of a tranquil place to write her memoirs. As she reaches the insula Pastoril, she is seen, in a metaleptic leap, turning to writing the very book the reader is about to close.

In contrast to Clareo and Florisea's exemplary tale of separation and reunion, Isea's story is framed as a case. Her life is narrated as a series of situations that require judgement and decision; it is not presented as an exemplum, a narrative that details and evidences virtuous and thus exemplary behaviour. What is specific about the form of the case, as André Jolles put it, is that "while it asks the question, it cannot give the answer. It imposes on us the duty of making 
a decision but does not offer the decision itself - what manifests itself in the case is the pondering, but not its result." ("Das Eigentümliche der Form des Kasus liegt nun aber darin, daß sie zwar die Frage stellt, aber die Antwort nicht geben kann, daß sie uns die Pflicht der Entscheidung auferlegt, aber die Entscheidung selbst nicht enthält - was sich in ihr verwirklicht, ist das Wägen, aber nicht das Resultat des Wägens," Jolles 158).

Reinoso writes on the threshold of what has been called casuistry's "century of maturity" (1556-1656, Jonsen/Toulmin 142; 152-175), only a few years after the Council of Trent instigated intense publication activity in the field of casuistry. In the Christian context (into which Reinoso had been forced as a converso), casuistry had emerged from the practice of confession. With the requirement of annual confession for all believers called for by the Papal bull Omnis utriusque sexus in 1215, the confessor emerged as a distinct figure, mediating between the parish flock and church authority. Invested with the institutional power to execute performative acts such as eucharistic consecration, imposing penance and granting absolution, his high moral rank conflicted with the often limited learning of the priests of lower hierarchical orders. As confessors were typically not experts in the highly specialized discourse of theology and the pertinent modes of reasoning, a genre of manuals, the so-called summae confessorum, emerged, with the Summa de poenitentia by Ramón de Peñafort (1175-1275), dating from 1221 (not printed before 1603 , but available in a host of manuscripts), being held as the architext of the genre. It was followed by a sea of summae which typically had technical titles like "Summa de casibus conscientiae", but were generally known under nicknames derived from the names of their authors - Raymundina, Astesana, Pisanella, Rosella, Baptistina, Tabiena, Monaldina, Sylvestrina, etc. This is testimony to their popularity, as are the many surviving copies (cf. Michaud-Quantin). These handbooks were supposed to enable a confessor to recognize sins and to judge them, to know whether they were to be considered venial or mortal, and if so, under which circumstances. In order to help him with this task, dubious cases and their solutions were collected first alphabetically and then shifted to a thematic order in the fifteenth century, variously following the seven capital sins or the Ten Commandments (Jonsen/Toulmin 153). But while Christian thinking in cases was nearing its apogee, the novela bizantina was only about to take shape.

\section{$3 \quad$ An Emerging Genre}

The early modern history of the Greek novel has frequently and predominantly been framed as the reception of Heliodorus' Aithiopika. In the last few 
decades, valuable efforts have been made at mapping the transformations and adaptations of the Heliodoran scheme. Much of the critical attention has been focused on Cervantes' Los trabajos de Persiles y Sigismunda (1617), while his eternal competitor Lope de Vega's El peregrino en su patria, published more than a decade earlier in 1604, is only gradually being recognized as the decisive innovation that it was. Beyond individual imitatio and aemulatio, however, there seem to be patterns of engagement with the ancient models that yield widely different results. While the Spanish novela bizantina, for example, tends to be set in contemporary Spain and presents melancholic, if not pessimistic scenarios of displacement and destitution, the French roman héroïque is concerned with a heroic antiquity. In the transcultural and transnational networks of writers, readers, buyers, translators, printers and impresarios, different poetological and literary contexts informed very different re-imaginations of the genre.

At the same time, the focus on Heliodorus privileges only one of the five known ancient authors of prose novels, thereby losing sight of another significant work equally known to early modern Europe, Achilles Tatius' Leucippe and Cleitophon. The first Greek-style novel in the Castilian language, which will be the focus in this chapter, was indeed not an imitatio of Heliodorus but rather a creative appropriation of Achilles Tatius' novel in eight books dating from the second century AD. It is fair to say that Heliodorus and Achilles Tatius belong to what could be termed 'the other' classical tradition, the tradition stemming from the Second Sophistic that also includes declamation and paradoxical encomia. The ancient prose novel is a blind spot within this neglected tradition, and even lacked a name: as Carlos García Gual has pointed out, despite producing literary terminology for tragedy, comedy, lyrical poetry, philosophy, historiography, biography, the epic, and more, neither the Greek nor the Roman culture felt a need to give a name to the prose novel, and much less to address it in their poetics (García Gual 16; Morgan 176-177 and the critical discussion in Goldhill). When these texts eventually became models for imitation in the early modern period, the genre was still unnamed.

Despite building on Achilles Tatius, Reinoso did not imitate his model faithfully, which is partly due to the fact that he modelled his narrative on an Italian translation of books $5^{-8}$ only. These had been published in Venice in 1546 under the title Amorosi ragionamenti by Lodovico Dolce, a Venetian humanist and editor in the service of Gabriel Giolito's press. ${ }^{4}$ But Reinoso went even

4 Zimic claims that Reinoso was familiar with the full text and feigned his debt to Dolce. He argues that Reinoso's chapter 20 shows parallels with Achilles Tatius' third book. See also Teijeiro Fuentes (1984) for more supposed traces of Achilles Tatius' chapters I-IV in Reinoso. 
further and reimagined the genre, responding to contemporary concerns and opening up new perspectives for generations to come. As has become evident, Reinoso strays quite far from Tatius' Leucippe and Cleitophon, adding, in the second part, seminal elements from the early modern European literary imaginaire, from knights errant and fighting gods to pastors and nymphs. Reinoso claimed that it was his intention to write "imitando y no romanzando" (65), taking Dolce's Amorosi ragionamenti as an inspiration rather than faithfully translating it into another vernacular. As we have seen, this is exactly what he did, at the same time cutting the learned digressions (Cruz Casado 1994: 26; Menéndez Pelayo II, 76).

Reinoso claimed to have stumbled upon Dolce's Amorosi ragionamenti at a bookseller's store in Venice. This serendipitous story, offered in the letter of dedication (65), has a somewhat disingenuous ring to it, since Reinoso and Dolce without doubt moved in the same circles in Venice. It is also no coincidence that it was none other than Reinoso's printer Giolito who had produced Dolce's book. Dolce was himself embroiled in a rapid series of editorial and philological attempts at recuperating the whole of Tatius, and it thus may warrant a brief detour in appreciation of this history.

The first Latin translation of Leucippe and Cleitophon by Luigi Annibale della Croce, published in Lyon in 1544, was incomplete, containing only books $5^{-8}$. In his dedicatory epistle to the Spanish ambassador in Venice, Diego Hurtado de Mendoza (to whom the Lazarillo de Tormes has been occasionally attributed), della Croce deplores the fragmentary transmission of the text, now aptly published under the title Narrationis amatoriae fragmentum, and the anonymity of its author (who wrote, as della Croce says, under the persona of Cleitophon). Of the historical context, however, della Croce is fairly certain, and he correctly places the author in the Second Sophistic (fol. $\mathrm{A2}^{\mathrm{v}}$ $\mathrm{A}_{3}{ }^{\mathrm{r}}$ ). Tatius' full text was made available in Latin translation shortly thereafter, in 1551, to be followed by French (1572), English (1597), Spanish (1617), German (1644), and Dutch (1652) versions. By 1554, less than ten years after the first Latin edition, Achilles Tatius was firmly established as the original author.

While this rapid sequence of translations and editions was underway, the text continued to be transmitted in manuscript. The Austrian National Library, for example, where I conducted most of my research for this chapter, holds a collection of excerpts from the novel under the title De Leucippes et Clitophontis amoribus dating from 1490-1510 (Cod.Phil.gr. 329). It was bought by Ogier Ghislain de Busbecq (as noted on fol. 112 imperial emissary who travelled to Constantinople in $1554 / 55$. It was in the context of the diplomatic relations and expeditions to the Osman Empire that these manuscripts kept coming to Europe. The long-term transmission of the 
Greek novel and its conversion into the novela bizantina ${ }^{5}$ is at the same time intricately linked to contemporary power relations and depends on a vital Mediterranean network of communication and political negotiation.

Leucippe and Cleitophon was the only one of the five extant Greek novels to rely on first-person narration. In line with Achilles Tatius' original, Reinoso retains this narrative device, but shifts narration from Cleitophon ${ }^{6}$ to the "sin ventura" Isea, as 'the other woman,' the counterpart of the original Melite. Isea is a "narradora omnisciente en primera persona" (Cruz Casado 1994: 25) who is cognizant of events she did not take part in, a logically impossible narratological mode that undermines the autobiographical character that has been attributed to Isea's story (cf. Deffis de Calvo 138).

\section{Lament and Detachment}

Glenn Most has established a link between the choice of first-person narration in Greek prose and the framing of the narration as a kind of lament. Speaking with a view toward both fictional and factual accounts, he argued that "a constraint seems to have tended to limit the production of autobiographical discourses in Classical Greece and to confine them to laments about misfortune or self-defences under attack" (Most 126). According to Most, telling one's own story had to take the form of a lament; it could not be an account of individual triumphs and successes. This social, and, as a consequence, literary constraint was coupled with an ethical ideal of self-sufficiency. "Greek theologians, at least from Plato through the Epicureans and Stoics," Most writes, "define the divine as that which stands in need of nothing outside itself", thus it is "not surprising that self-sufficiency comes to be one of the characteristics most frequently attributed to the man of wisdom and virtue" (128).

Reinoso did not cater to the norms of ancient Greek society but rather to the predilections of an early modern reading public. His approach clearly hit a nerve; and despite his book seeing only one edition, the tone Reinoso introduced into the Castilian vernacular worked its way into other early modern texts. Lope de Vega's El peregrino en su patria, for instance, which got rid of the pastoral and chivalric elements, firmly established the novela bizantina as a

5 As elaborated by Menéndez Pelayo; Teijeiro Fuentes 2007; Torres.

6 Cleitophon is actually an intradiegetic narrator, prompted to tell his story by 'the author' at the beginning when the two meet in front of a painting of Europa and the bull, but this narrative bracket is not closed at the end. 
tale of destitution and displacement in the contemporary world. Where Isea describes herself as "sin él [i.e. Clareo], y sin marido, y sin honra, y sin ningún descanso" (Núñez de Reinoso 137), Lope frames the fate of his Peregrino - "[el] largo proceso de sus trabajos", as one of continuous demotion:

pues de cortesano vino a soldado, de soldado a cautivo, de cautivo a peregrino, de peregrino a preso, de preso a loco, de loco a pastor y de pastor a mísero lacayo de la misma casa que fue la causa original de su desventura $[\ldots]$.

LOPE DE VEGA $472-473$

Lope's third-person narration does abstain from complaint and matter-offactly lists the episodes of the hero's downward spiral, but this is neither an idealising nor a hopeful narrative. The desperate mood and the ethical goal of self-sufficiency are eventually lifted from the narrow and rare frame of firstperson narration and come to inform the genre or at least its most remarkable exponents in the early modern period (cf. Brusa).

Despite enriching the Hellenistic scheme with both chivalric and pastoral elements, Reinoso firmly denied having written a chivalric romance, denouncing the shallowness that supposedly plagued the genre: "[...] quien a las cosas de aquel libro diere nombre de las vanidades de que tratan los libros de caballerías, dirá en ello lo que yo en mi obra no quise decir [...]" (Núñez de Reinoso 197, n. 145). In the face of the overwhelming success of chivalric novels in the early modern period, this is nevertheless quite a common repudiation, shared for example in one of the era's most popular works, the Libro áureo de Marco Aurelio (1543) by Antonio de Guevara. Guevara expressed his concern about the many young men who spent, or rather wasted, their time immersing themselves in the adventures of Amadís, Primaleón, Lisuarte and all the others (Guevara, prólogo general). But this damning judgment does not do justice to how the libros de caballerías were actually read. They were taken as manuals that staged, in action, ideals of comportment for a (generally male) elite. The Amadis de Gaula and its sequels

became the manual of the finished caballero, the epopee of faithful lovers, the code of honour which moulded many generations. Even in its superficialities and frivolities, it remained throughout the sixteenth century the textbook of polite deportment, the oracle of elegant conversation, the repertory of good manners and of gallantry in forms of address.

BRODRICK 4 O (SEe alsO PLACE; CACHO BLECUA; RIEGER) 
Libros de caballerías were read for action, yet the chivalric parts of Clareo $y$ Florisea do not attribute agency to Isea; she is certainly not depicted in action.

Even though the doncella andante is an occasional figure in sixteenthcentury chivalric novels (González Rovira 180-181; Marín Pina), Isea's role in what is essentially Felesindos' story in the second part of the novel deviates from established patterns. Not only is she a widow rather than a virgin (which is due to her being the counterpart of Achilles Tatius' Melitte), she is also not fully present in her own story. We as readers are the audience for a series of knightly adventures, as is Isea. It is as if she is not even present in the diegetic world. None of the many characters they encounter takes issue with a fully armoured knight being accompanied by a young woman on foot. They wander through landscapes that were not unfamiliar to readers of the chivalric novels of the time, thus traversing an entirely literary landscape. And what is more, nobody engages with Isea; she has no dialogic exchange with the characters they encounter. She observes and sometimes comments in her narrator's voice, but never engages directly with the various people they encounter. Isea, who is present with Felesindos all the time, turns more and more into a heterodiegetic narrator, leaving no trace in the narrated world, but rather offering insight into the conscience of characters, such as the highly personal thoughts of the sister of the king of Cyprus, Estrellinda, whom they meet on their way and who passes a sleepless night (Núñez de Reinoso 155). When watching a courtly gathering where nobody interacts with her, Isea is overcome with emotion and starts crying, to which, again, not a single person reacts - contrary to a scene following suit in which the queen begins to cry and is immediately comforted by Felesindos (Núñez de Reinoso 168):

Yo, estando ansí mirando aquellas damas y caballeros, sin saber por qué causa, sentí en mí una nueva mudanza y soledad, de tal suerte que los ojos se me comenzaron a henchir de lágrimas [...].

NÚÑEZ DE REINOSO 166

Isea's role has been described as that of a reporter of Felesindos' adventures (Cruz Casado 1994: 34), but while she does indeed narrate the course of events in more detail than actually afforded by the device of first-person narration, her mental disposition is quite different. Isea acts like a reader, silently observing moving scenes and crying when hearing sad stories, not being concerned with or ashamed of her emotions - because nobody can see her, it seems. Only when they reach Alexandria again does Isea become a full-fledged character and assume agency in the diegesis. For a large part of the narrative, Isea thus 
prefigures the reader of her own story who will be a distant observer of her fate and who, hopefully, will take her case as a prompt for moral reflection.

The pastoral world, on the other hand, is interspersed throughout yet contained in the heterotopias of the several mythical islands that can only be reached by boat. Pastoral intermezzi were common in libros de caballerías: both the Amadis de Grecia (1530) and the first three parts of the Florisel de Niquea (1532-35) contain pastoral episodes, characterised by the presence of shepherds (pastores) and the backdrop of the locus amoenus, thus foregrounding the setting, whereas the action in the libros de caballerías is typically devoid of descriptions of the surroundings (Cravens 40). When Isea eventually takes up residence on the insula Pastoril, she does not subject herself to pastoral pursuits: she does not engage in the leisurely debates and songs on love and longing typically favoured by the shepherds. The two worlds - Isea's travels and the chivalric and pastoral adventures she witnesses - do not merge. Thus, while Reinoso does not present his readership with a clear-cut imitation of Achilles Tatius' novel, but rather integrates elements of two of the most popular contemporary prose genres, he sets Isea apart from these traditional fictional worlds and lets her lament underwrite the whole story as a kind of basso continuo, setting tone and theme for the emerging genre of the novela bizantina. ${ }^{7}$

Not just in the chivalric and pastoral settings, but even in Reinoso's explication of the purpose of his work, Isea is marginalised. Reinoso claims to have written the "historia de Florisea" (a telling slip of the pen)

para avisar a bien vivir, como lo hicieron graves autores que, inventando ficciones, mostraron a los hombres avisos para bien regirse, haciendo sus cuentos apacibles por inducir a los lectores a leer su escondida moralidad [...].Y ansí ninguna cosa hay en toda aquella historia que no tenga algún ejemplo para bien vivir.

NÚÑEZ DE REINOSO 196, n. 145

And what are the examples we are supposed to note? Married couples should learn from Clareo and Florisea how important it is to be faithful and virtuous; from Felesindos, that men need to show strength in order to eventually reach peace of mind; and from Isea? “[...] cuán bien están los hombres en sus tierras, sin buscar a las ajenas" (Núñez de Reinoso 196, n. 145).

This maxim is of course the exact opposite of Isea's story. Her example is, at best, one ex negativo, her travails proving that one should not travel. This peculiar lesson alludes to the discourse of moral philosophy and more specifically

7 For this genre characteristic see Brusa/Traninger. 
to Seneca's Epistulae morales ad Lucilium. In letters 28 and 104 it is made amply clear that travel will never offer an escape from one's troubles: "Animum debes mutare, non caelum" ("You need a change of soul rather than a change of climate", ep. 28, 1). Evidently, the novel needs to be read in conjunction with the larger moral-philosophical literature on which it builds and which, in turn, underwrites its otherwise elliptical messaging. Isea's story is squarely placed in a cluster of ethical concerns that was highlighted and discussed in a broad range of literature, from the classical authors that were required reading in the Renaissance classroom, such as Seneca; to the moral tales in the mirrors of princes that were often of far eastern and Arab descent; and to the adages and accompanying essays made popular above all by Erasmus of Rotterdam. ${ }^{8}$

Isea's story is one of despair and displacement, which she claims to share with her readers, or rather reader, whom she imagines as "otra Isea" (another Isea) who experiences similar hardships and turns to her text to commiserate, but also to deliberate:

Si mis grandes tristezas, trabajos y desventuras por otra Isea fueren oídas, yo soy cierta que serán no menos lloradas que con razón sentidas; pero con todo, pienso que pues mis tristes lágrimas ablandaron y enternecieron las duras piedras, que ansí hará a los blandos y tiernos corazones, so pena que no siendo así, confesarán que son más duros que las duras peñas. Esta mi obra, que solamente para mí escribo, es toda triste, como yo lo soy; es toda de llanto y de grandes tristezas, porque ansí conforme con todas mis cosas y tenga el hábito que yo tengo. Cuenta fortunas ajenas porque mejor se vea cuán grandes fueron las mías, y aun al presente son; no lleva estilo, ni orden, porque yo no quiero loor ni me conviene ninguno.

NÚÑEZ DE REINOSO 67

This is telling, not showing. Still, the passage sets the tone for the whole narrative arc in which Isea does not tire of not only recounting her fate, but commenting on it in this desperate vein. It may have been this tearful sentiment that prompted several critics to suggest that the novel was geared towards a predominantly female readership (Teijeiro Fuentes 1991: 11; González Rovira 172). I would, however, insist that there is no historical evidence that points to such a specific and comparatively narrow audience. Rather, these statements

8 I will discuss these connections in detail in a forthcoming book on Patterns Which Connect: Towards a Global Literary History. 
belong to a long-standing pattern of discrediting the genre (Egger 110-112). The claim probably builds on the customary happy ending involving the reunion of the separated lovers and its interpretation as romantic (in the modern sense) wish fulfilment catering to specifically female desire rather than the reestablishment of order. Indeed, the story of Clareo and Florisea does end with their reunion, but this happens early on, before Isea embarks on her travels.

Isea does not tire of framing her story as an account of insurmountable hardship, but at the same time she demonstrates an autarkeia that is unheard of for a woman of her time. Isea's travels are undertaken out of her own volition, turning her from the unloved, ersatz Flor-isea into a tireless traveller surviving an Od-isea. That she tearfully, but voluntarily takes leave of her friends and family to roam the world; that she joins a knight errant for part of the way, yet without acting like the damsel in distress, but rather walking alongside him; that she eventually sets off for Europe in search of the place that would allow for a self-sufficient existence - that this kind of agency is attributed to a woman highlights all the more that Isea's story is very much a meditation on human judgement in the face of adversity.

\section{$5 \quad$ Casuistry and the Prose Novel: A Shared Genealogy}

Casus conscientiae, cases of conscience, required a specific type of judgement: "The ultimate act of 'conscience' was a judgement in which the universal and the particular were known together (con-scire)" (Jonsen/Toulmin 153). And not least, this act of judgment needed to result in action, as stressed by Thomas Aquinas, which is why casuistry's methodological base was the syllogismus practicus, the practical syllogism that supplanted the conclusion by action (Jonsen/Toulmin 129; Summa theologica Ia, q. 79, a. 13; Kittsteiner 193-203). From its earliest beginnings in the penitential literature of the Middle Ages, casuistry

[...] emphasized acts and decisions as central elements in the moral life. It defined the basic structure of any moral situation: an individual, characterized in a certain way, performs an act of a certain kind, with a specific intention, and in a particular state of mind. It stressed discrimination between acts and their evaluation in the light of the stated circumstances.

JONSEN/TOULMIN 100 
Students of medieval and early modern Christian casuistry have noted that the casuists resorted to ancient rhetoric in order to tame the proliferation of circumstances (cf. Maryks). Rhetoric, of course, had long reduced potentially infinite circumstances to a topical grid, one that resonates through time and is still drilled into the heads of every journalism student today: quis, quid, ubi, quibus auxiliis, cur, quomodo, quando - who, what, where, by which means, why, how, when (Jonsen/Toulmin 132). D.W. Robertson has argued that, in addition, casuistical thinking is built specifically on the rhetorical distinction between thesis and hypothesis, the thesis being a general argument, the hypothesis taking into consideration the individual circumstances of a case (Robertson). Cicero discussed the distinction as an ancient one that could be traced back to Hermagoras (Cic. De inv. I, 6, 8; Bonner 5-11). Thesis and hypothesis were framed as resorting to philosophy and rhetoric, respectively, ${ }^{9}$ a view supported and confirmed by Boethius, who ensured their transmission to the Middle Ages (Leff 10). But in practice thesis and hypothesis were closely intertwined, and discussed as such, above all by Quintilian (Inst. orat. III, 5 , $5^{-10}$ ): while rhetoric was typically concerned with the specificity of individual cases, those could easily be stripped away to make a more general point and add weight to the argument.

Against this background, a shared genealogy of the novela bizantina and Christian casuistry emerges, and at its root is, surprisingly, the Second Sophistic of the Roman Empire. Mikhail Bakhtin pointed out that the Greek novel did feed on the rhetorical casuistry of the Second Sophistic (Bakhtin 12). ${ }^{10}$ The hypothesis forms the basis for the Second Sophistic practice of declamation, which was all about exploring individual cases under an abundance of circumstances bordering on the absurd. Of particular relevance are the so-called controversiae, fictional pleadings in imaginary court cases. The intriguing aspect of these controversiae was that not only were the cases, the 'lawyer' or 'counsel', the parties of conflict and the persons involved as well as the circumstances fictional, but also the laws which provided the framework for the pseudolegal argument. Declamation thus formed an artificial cosmos of reference, independent of contemporary judicial praxis (Bonner 51-70; Russell 87-105; Bloomer).

The extant argumenta for these controversiae summarise complex and improbable cases, which appear to be nothing more than extravagant entertainment. Yet recent research has found that these fantastic themes and

$9 \quad$ See Clarke; Throm.

10 For a critical discussion see Selden; for narratological implications, Traninger. 
constellations did in fact serve a conservative purpose: that of immersing students of rhetoric in the set of norms and values of a Roman citizen, of a pater familias and slave holder by contemplating these very values in outrageous and highly contrived situations (Bloomer 1997; Kaster; Gunderson 29-33). The techniques of declamatory rhetoric informed the prose novel, from characters' speeches to the fleshing out of complex situations in persuasive detail (Webb 535-538).

While medieval casuistry was the confessors' business, a sea change happened in the early modern period when cases of conscience were increasingly handed from trained specialists to the individual. Now confessors were

[...] to teach ordinary people how to examine their own moral lives and how to communicate about them with another person - namely, their confessor or spiritual director. [...] The common people could now be shown the relative importance of intentions, dispositions, consequences, and circumstances to the moral evaluation of their acts.

JONSEN/TOULMIN 142

This is not, as has often been claimed, a phenomenon brought about by the Reformation. Rather, an interiorisation of conscience took place across denominations in the early modern period, complementing as well as changing penitentiary practice.

As casuistry is handed over from priests to believers, this is accompanied by two shifts: first, case collections in the summae confessorum were complemented by fictional cases unfolding in literary texts. Second and in conjunction with this, we observe a shift from the oral-aural event of confession to the oral-aural event of sociable reading. The concept of interiorisation would seem to suggest that solitary immersion in a literary text and individual reflection would replace the dialogic interaction of confession, but all we know about reading in the early modern period points to a vastly different setting. With narrative texts staging individual action and moral dilemmas in scenarios of exuberant circumstance - think of Isea's fortunas ajenas - the judgment is handed to the reader or readers who were, more often than not, forming reading communities. It was these reading communities on which the early periodical press could later capitalize, as for example when Donneau de Visé invited the readers of the Mercure galant to weigh in on the moral dilemma underwriting Mme. La Fayette's La Princesse de Clèves (1678). He received so many responses that he could fill the journal's issues for an entire year (Dejean 6o-61). Reinoso himself does not offer much in terms of dilemmatic 
reasoning, but rather invites compassion as much as judgment, and in so doing delegates the task of moral reflection to his readers.

But why would casual readers feel attracted by such a dire view of the human condition? Clareo y Florisea was written by a converso in exile, a muchdiscussed fact that inspired biographical and allegorical readings of the novel (Bataillon; Rose 1971; Cruz Casado 1988; Teijeiro Fuentes 1991; Marguet). But the topic of exile and the fundamental loss of certainties was not exclusive to the early modern converso community - even if they, of course, suffered to an extent unimaginable to other groups. One of the reasons why the refashioning of the Greek novel was so successful was because it addressed or made accessible in literary format the experience of uprootedness, deprivation, displacement, destitution and loss of status and prerogatives. Pedro Mexía's contemporary and hugely popular Silva de varia lección (1540) with its extensive chapters on destierro (II, 20 \& 21), compiling a broad range of examples from literature and history, amply documents a profound interest in questions of displacement, loss of rank, and destitution. This was in particular an experience not of the lower classes, who found a literary figuration in the picaro. Indeed, the novela picaresca, invented at around the same time as the novela bizantina, tells the complementary story: that of a petty criminal or low life and their ascent to a moderate livelihood.

When Isea refers to herself as "peregrina, perdida, acosada y estranjera" (Núñez de Reinoso 141), she certainly does not allude to Christian peregrinatio in the sense of a pilgrimage. Of course, peregrinatio and the picturing of human life as a pilgrimage was an immensely productive metaphor in Golden Age literature (cf. Hahn; Nitsch; Ehrlicher). A prominent line of interpretation is that of a Counter-Reformation piety that found its place in the transformed Greek novel, featuring man as a "peregrino, romero por tierra" (Teijeiro Fuentes 1991: 9), turning the novela bizantina into a vehicle of Catholic reform (cf. Vilanova). But not least Reinoso's many allusions to Ovid's Tristia (Gonzalez Rovira 172) firmly establish his peregrina as a foreigner rather than a pilgrim, and they point to the deplorable status of an exile rather than the pursuits of a godly wanderer (Rose 1971: 126).

The peregrina/peregrino of the early modern Spanish novela bizantina is a noble, or at least high-standing, character who has to get by having lost their signs of status and identity. This narrative of survival is a trope for an all-toocommon experience for early modern courtiers: with every succession (and at times they came at short intervals), the scrambling for positions at court began anew. Favourites of deceased kings could never count on the continuation of their luck, quite to the contrary. Chances were that there would be droves of rivals who had long awaited the opportunity to move past them. What would 
have been a handsome income in the form of a pension or an office could disappear overnight. Or someone could be banned from the corte, Madrid, or Castile as a whole, as had happened to Lope de Vega for two and eight years respectively, or struggle for decades to secure patronage in the first place (Wright). And this kind of existential insecurity was not limited to the secular courts: Mario Biagioli has shown in his marvellous book on Galileo as a courtier how the Papal Court in Rome was subject to the same, if not even more drastic mechanisms of patronage and shifting fortunes (Biagioli esp. 316-323).

The refashioned Greek novel plays to these existential questions. As a genre, it is darker and more serious than all the other prose genres that emerge at the time. Criticized by later generations of scholars as sappy, the de rigueur happy ending and the reunion of the separated lovers seem not to be at the core of the narrative impact. Rather, by adopting and adapting the exuberant Greek scenarios, the novela bizantina offers a mise-en-scène of overwhelming circumstances and a cast of characters whose desperate attempts at navigating them puts the reader in charge of contemplating cases of conscience - those incurred by the characters, but just as much their own.

\section{Works Cited}

Bakhtin, Mikhail. "The Bildungsroman and Its Significance in the History of Realism (Toward a Historical Typology of the Novel)." Speech Genres and Other Late Essays. Austin, TX: University of Texas Press, 1987: 10-59.

Bataillon, Marcel. "Alonso Núñez de Reinoso y los marranos portugueses en Italia." Varia lección de clásicos españoles. Madrid: Gredos, 1964: 55-80.

Biagioli, Mario. Galileo Courtier. The Practice of Science in the Culture of Absolutism. Chicago, IL/London: The University of Chicago Press, 1993.

Bloomer, W. Martin. "Schooling in persona: Imagination and Subordination in Roman Education." Classical Antiquity 16.11 (1997): 57-78.

Bloomer, W. Martin. "Roman Declamation: The Elder Seneca and Quintilian." $A$ Companion to Roman Rhetoric. Eds. William J. Dominik and Jon Hall. Malden, MA: Blackwell, 2007: 296-306.

Bonner, S.F. Roman Declamation in the Late Republic and Early Empire. Liverpool: Liverpool University Press, 1969.

Brodrick, James sJ. Saint Ignatius Loyola: The Pilgrim Years. London: Burns \& Oates, 1956.

Brusa, Paolo. Peregrinatio als Novation. Heliodors Muster in Lope de Vegas El peregrino en su patria (1604) und seine Folgen für die novela helenizante. Ph.D. dissertation, Freie Universität Berlin, 2021 (forthcoming). 
Brusa, Paolo/Traninger, Anita. Lesekontext und Affektregime: Probleme der Gattungsmischung in der Erzählprosa des Siglo de Oro. FOR 2305 Working paper, Freie Universität Berlin, 2018 (10.17169/refubium-508).

Cacho Blecua, Juan Manuel. Amadís: Heroísmo mítico cortesano. Madrid: Cupsa, 1979.

Clarke, M.L. "The Thesis in the Roman Rhetorical Schools of the Republic." The Classical Quarterly 1.3-4 (1951): 159-166.

Cravens, Sydney Paul. “The Insula Deleitosa Tale in Alonso Núñez de Reinoso's Clareoy Florisea: A Tribute to Feliciano de Silva." Hispanófila 64 (1978): 1-6.

Cruz Casado, Antonio. "Exilio y peregrinación en el Clareo y Florisea (1552), de Alonso Núñez de Reinoso." 1616, Anuario de la Sociedad Española de Literatura General y Comparada IV-VII (1988): 29-35.

Cruz Casado, Antonio. 'La inacabada 'Historia del Caballero Felesindos', de Alonso Nuñez de Reinoso, en Clareo y Folorisea (1552)." Revista de literatura $5^{6.111}$ (1994): 23-38.

Deffis de Calvo, Emilia I. "El cronotopo de la novela española de peregrinación: Alonso Núñez de Reinoso y Lope de Vega." Criticón $5^{6}$ (1992): 135-146.

DeJean, Joan E. Ancients Against Moderns: Culture Wars and the Making of a Fin de Siècle. Chicago, IL/London: University of Chicago Press, 1997.

Egger, Brigitte Maria. "The Role of Women in the Greek Novel: Woman as Heroine and Reader." Oxford Readings in the Greek Novel. Ed. Simon Swain. Oxford: Oxford University Press, 1999: 108-136.

Ehrlicher, Hanno. "Poetas peregrinos: autoconfiguraciones autoriales en las novelas de aventuras de Lope de Vega y Miguel de Cervantes." eHumanista/Cervantes 1 (2012): 211-225.

García Gual, Carlos. Historia de amantes peregrinos. Las primeras novelas. Discurso leído el día 17 de febrero de 2019. Madrid: Real Academia Española, 2019.

Goldhill, Simon. “Genre.” The Cambridge Companion to the Greek and Roman Novel. Ed. Tim Whitmarsh. Cambridge: Cambridge University Press, 2008: 185-200.

González Rovira, Javier. La novela bizantina de la Edad de oro. Madrid: Gredos, 1996.

Grunebaum-Ballin, Paul.Joseph Naci duc de Naxos. Paris: Mouton, 1968.

Guevara, Antonio de. Marco Aurelio, con el Relox de principes. Sevilla: Cromberger, 1543. Gunderson, Erik. Declamation, Paternity, and Roman Identity. Authority and the Rhetorical Self. Cambridge University Press, 2003.

Hahn, Jürgen. The Origins of the Baroque Concept of Peregrinatio. Chapel Hill, NC: University of North Carolina Press, 1973.

Hunger, Herbert. Katalog der griechischen Handschriften der Österreichischen Nationalbibliothek 1: Codices historici, codices philosophici et philologici. Vienna: Prachner/Hollinek, 1961.

Leff, Michael C. “The Logician's Rhetoric. Boethius' De Differentiis Topicis, Book IV.” Medieval Eloquence: Studies in the Theory and Practice of Medieval Rhetoric. Ed. 
James J. Murphy. Berkeley/Los Angeles/London: University of California Press, 1978: 3-24.

Jolles, André. Einfache Formen. Legende/Sage/Mythe/Rätsel/Spruch/Kasus/Memorabile/ Märchen/Witz. Halle/Saale: Niemeyer, 1956.

Jonsen, Albert R./Toulmin, Stephen. The Abuse of Casuistry: A History of Moral Reasoning. Berkeley/Los Angeles/London: University of California Press, 1988.

Kaster, Robert A. "Controlling Reason: Declamation in Rhetorical Education at Rome." Education in Greek and Roman Antiquity. Ed. Yun Lee Too. Leiden/Boston: Brill, 2001: $317-37$.

Kittsteiner, Heinz D. Die Entstehung des modernen Gewissens. Frankfurt: Insel, 1992.

Marguet, Christine. "De Leucipa y Clitofonte de Aquiles Tacio a la Historia de los amores de Clareo y Florisea de Alonso Núñez de Reinoso: un caso de reescritura novelesca entre traducción y creación." Criticón 76 (1999): 9-22.

Marín Pina, Ma Carmen. "La doncella andante en los libros de caballerías españoles: La libertad imaginada (II)." eHumanista 16 (2010): 221-239.

Maryks, Robert Alexander. Saint Cicero and the Jesuits. The Influence of the Liberal Arts on the Adoption of Moral Probabilism. Aldershot: Ashgate, 2008.

Menéndez Pelayo, Marcelino. Orígenes de la novela. Madrid: Gredos, 2008.

Mexía, Pedro. Silva de varia lección. Ed. Antonio Castro, 2 vols. Madrid: Cátedra, 1989.

Michaud-Quantin, Pierre. Sommes de casuistique et manuels de confession au moyen âge (XII-XIV siècles). Louvain/Lille/Montreal: Nauwelaerts, 1962.

Morgan, J.R. "Make-Believe and Make Believe: The Fictionality of the Greek Novels." Lies and Fiction in the Ancient World. Ed. Christopher Gill, Austin, TX: University of Texas Press, 1993: 175-229.

Most, Glenn W. “The Stranger's Stratagem: Self-Disclosure and Self-Sufficiency in Greek Culture." The Journal of Hellenic Studies 109 (1989): 114-133.

Nitsch, Wolfram. "Das Subjekt als peregrino. Selbstbehauptung und Heteronomie in Góngoras Lyrik." Welterfahrung - Selbsterfahrung. Konstitution und Verhandlung von Subjektivität in der spanischen Literatur der frühen Neuzeit. Eds. Wolfgang Matzat and Bernhard Teuber. Tübingen: Niemeyer, 200o: 363-377.

Núñez de Reinoso, Alonso. Historia de los Amores de Clareo y Florisea, y de los Trabajos de Ysea: con otras obras en verso, parte al estilo Español, y parte al Italiano. Agora nuevamente sacada a luz. Venice: Gabriel Giolito de Ferrari \& brothers, $155^{2}$.

Núñez de Reinoso, Alonso. Los amores de clareo y Florisea y los trabajos de la sinventura Isea. Ed. Miguel Angel Teijeiro Fuentes. Cáceres: Universidad de Extremadura, 1991. Place, Edwin B. "El Amadís de Montalvo como manual de cortesanía en Francia." Revista de Filología Española 38 (1954): 151-169.

Rieger, Dietmar. “Amadis und andere.Zu den literarischen Leitfiguren 'ritterlicher' Eliten des 16. Jahrhunderts." Die Inszenierung der heroischen Monarchie. Frühneuzeitliches 
Königtum zwischen ritterlichem Erbe und militärischer Herausforderung. Ed. Martin Wrede, Munich: Oldenbourg, 2014: 40-56.

Robertson, D.W. "A Note on the Classical Origin of 'Circumstances' in the Medieval Confessional." Studies in Philology 43.1 (1946): 6-14.

Rose, Constance Hubbard. Alonso Núñez de Reinoso: The Lament of a Sixteenth-Century Exile. Rutherford/Madison/Teaneck: Fairleigh Dickinson University Press, 1971.

Rose, Constance Hubbard. "New Information on the Life of Joseph Nasi Duke of Naxos: The Venetian Phase." The Jewish Quarterly Review 6o.4 (1970): 330-344.

Rose, Constance Hubbard. “Alonso Núñez de Reinoso's Contribution to the Creation of the Novel." Creation and Re-Creation: Experiments in Literary Form in Early Modern Spain: Studies in Honor of Stephen Gilman. Eds. Nora Weinerth, Ronald E. Surtz and Stephen Gilman. Newark, DE: Juan de la Cuesta, 1983: 89-103.

Russell, D.A. Greek Declamation. Cambridge: Cambridge University Press, 1983.

Saporta Beja, Nicolas. Deux grandes figures juives de la Renaissance: Doña Gracia Mendesia Nasi, Don Joseph Nasi, duc de Naxos. Paris: Éditions Vidas Largas, 1985.

Selden, Daniel L. "The Anti-Sophistic Novel." The Oxford Handbook of the Second Sophistic. Eds. Daniel S. Richter and William A. Johnson. Oxford: Oxford University Press, 2017: 421-446.

Seneca. Ad Lucilium epistulae morales. Trans. Richard M. Gummere, 3 vols. Loeb Classical Library. Cambridge, MA: Harvard University Press (1917, 1920, 1925).

[Tatius, Achilles]. Narrationis amatoriae fragmentum è graeco in latinum conversum, L. Annibale Cruceio interprete. Lyon: Sebastian Gryphius, 1544.

[Tatius, Achilles]. Amorosi ragionamenti. Ne i quali si racconta un compassionevole amore di due amanti, tradotti per M. Lodovico Dolce, dai fragmenti d'uno antico scrittor greco: \& di nuovo corretti \& ristampati. Venice: Gabriel Giolito de Ferrari, 1547.

Tatius, Achilles. Leucippe and Clitophon. Trans. with notes by Tim Whitmarsh. Oxford: Oxford University Press, 2001.

Teijeiro Fuentes, Miguel Ángel. “Clareo y Florisea o la historia de una mentira." Anuario de Estudios Filológicos 7 (1984): 353-359.

Teijeiro Fuentes, Miguel Ángel. “Introducción.” Alonso Núñez de Reinoso: Los amores de Clareo y Florisea y los trabajos de la sin ventura Isea. Ed. Miguel Ángel Teijeiro Fuentes, Cáceres: Universidad de Extremadura, 1991: 7-64.

Teijeiro Fuentes, Miguel Ángel. "Marcelino Menéndez Pelayo en los orígenes de los estudios bizantinos." Orígenes de la novela. Estudios. Eds. Raquel Gutiérrez Sebastian and Borja Rodríguez Gutiérrez. Santander: Sociedad Menéndez Pelayo, Universidad de Cantabria, 2007: 261-277.

Thomas Aquinas, Summa theologiae, Corpus Thomisticum (corpusthomisticum.org/ iopera.html, accessed 21 December, 2020).

Throm, Hermann. Die Thesis. Ein Beitrag zu ihrer Entstehung und Geschichte. Paderborn: Schöningh, 1932. 
Torres, José B. “ ¿Novela bizantina o novela helenizante? A propósito de un término consagrado." Ars bene docendi: homenaje al profesor Kurt Spang. Eds. Ignacio Arellano Ayuso, Víctor García Ruiz and Carmen Saralegui Platero. Pamplona: EuNSA, 2009: 567-574.

Traninger, Anita. "Erzähler und persona. Rhetorik und Narratologie zwischen Mündlichkeit und Schriftlichkeit." Wege moderner Rhetorikforschung. Klassische Fundamente und interdisziplinäre Entwicklung. Eds. Gregor Kalivoda and Gert Ueding, Berlin/Boston: de Gruyter, 2013: 185-210.

Vega Carpio, Lope de. El peregrino en su patria. Ed. Juan Bautista Avalle-Arce. Madrid: Castalia, 1973.

Vilanova, Antonio. “El peregrino andante en el Persíles de Cervantes." Boletín de la Real Academia de Buenas Letras de Barcelona 22 (1949): 97-159.

Webb, Ruth. "Rhetoric and the Novel: Sex, Lies and Sophistic." A Companion to Greek Rhetoric. Ed. Ian Worthington. Williston: Blackwell, 2006: 526-541.

Wright, Elizabeth R. Pilgrimage to Patronage: Lope de Vega and the Court of Philip III, 1598-1621. Lewisburg: Bucknell University Press, 2001.

Zimic, Stanislav. "Alonso Núñez de Reinoso: traductor de 'Leucipe y Clitofonte." Symposium 21.2 (1967): 166-175. 